\title{
The Effect of Internal Communication on Employees' Commitment to Change in Malaysian Large Companies
}

\author{
Leonis Marchalina (Corresponding Author) \\ College of Business, Universiti Utara Malaysia, Malaysia \\ E-mail: leonismarchalina@gmail.com
}

Hartini Ahmad

College of Business, Universiti Utara Malaysia, Malaysia

Received: Dec. 30, 2016 Accepted: Jan. 11, 2017 Published: January 20, 2017

doi:10.5296/bms.v8i1.10629 URL: http://dx.doi.org/10.5296/bms.v8i1.10629

\begin{abstract}
Employees' commitment seems to be vital in decision making for any organizations in order to be able in business competition and to adapt with changes. The commitment among employees can be a crucial tool for improving their performance in organizations. Communication is needed to raise awareness among employees on the need of change as well as creating the readiness to the change whereby it leads to the commitment to change. The objective of this paper is to examine the influence of internal communication on employees' commitment to change. Apparently, this issue likely has attracted the attention among either scholars or researchers. The theoretical contribution has been added in this study by investigating the effect of internal communication in influencing employees' commitment to change. A survey of structured questionnaire was conducted in five-hundred fifty employees in Malaysian large companies. The significant relationship has been found between internal communication and employees' commitment to change through multivariate regression analysis. Moreover, the implications to practice and theory are discussed.
\end{abstract}

Keywords: Employees' commitment to change, Internal communication, Malaysian large companies, Organizational commitment 


\section{Introduction}

Change is a law of nature that occur inevitably. It was observed that the change ought to be happen as the environment itself is changing also whether in a small scale or in a large scale. This is because it cannot be stagnant if it wants to still exist in the business environment. This view is supported by Burke (2013) stated that organization ought to change in order to survive in the highly competitive and dynamic environment. The environment is dynamic as a natural reaction to the natural changes, and so does the organizations need to change as well (Child, 2015; Walmsley \& Lewis, 2014). Therefore, it is understood that change is crucial for the development of organization's performance. We realize the organization change not merely for the sake of the change itself, instead, it was about learning and regenerate the organization. It could be done through inculcate the required change to the individuals, organizations or groups so that those will be more competitive in the future, which is in line with previous studies (such as Cummings \& Worley, 2014; Wooten \& Hoffman, 2016).

Among the important debates on the change failures in the organisation which leads to the business failures are in terms of debt repayments (Ong et al., 2011), management frauds (Yap, 2012), lack of leaders' skills and competencies (Ahmad \& Seet, 2009), and commitment to change (Burke, 2002; Gelaidan \& Ahmad, 2010; Probst \& Raisch, 2005). Recently, many focuses on the need to study on the commitment to change because it is actually becoming the unanswered phenomenon in the country in general and company in specific (Abrell-Vogel \& Rowold, 2014; Chen et al., 2012; Erkutlu \& Chafra, 2016; Rogiest et al., 2015).

There is little evidence on the commitment to change in the large companies as still few studies reveal the key factors that contribute to the commitment to change particularly on the individual levels. To the researcher understanding, most of literatures have been studied that most of change failures occurred in Small-Medium Enterprises (SMEs) (e.g. Jaafar \& Abdul-Aziz, 2005; Ahmad \& Seet, 2009; Paulet et al., 2014) but a very few concerned on large companies, particularly in Malaysia. Large companies in America pledged and committed to fight the climate change (Fortune, 2015). Competition and business change can affect the ability of companies to maintain or increase their company's profit. Whereas, the effect mostly affected in large companies due to their business circumstances. The change affects globalisation through the increasing of business competition and advanced of technology (Tuanmat \& Smith, 2011). This kind of change mostly occur in large companies. The global crisis hits the French companies to the sectors that highly used in mediocre consumption particularly in consumer products and automotive industries (Bricongne et al., 2012), and yet in banking sectors as respond to the financial crisis (RT Television Network, 2015).

Similarly, the automotive industries play a key role for Malaysian economy that grew fast in the past few years (Mousavi et al., 2011) though it was hit the financial crisis based on KPMG International (2008). The global crisis affected the four regional economies in Asia such as Singapore, Indonesia, Thailand and Malaysia. The slow China's economy, as Malaysia's largest business partner, has affected the degenerate its GDP growth. The 
dynamic of globalization affect economy in Malaysia that encouraged Malaysia to change. It requires the change in management and operations in most businesses (Tuanmat \& Smith, 2011). Change initiatives are somewhat the norm for companies currently, regardless their size, sector or industry of their company (Bellou \& Chatzinikou, 2015). Organizational change is required in any companies in responding the global crisis that occurred (Ahmad \& Gelaidan, 2011).

In order to implement change effectively, it requires commitment in any organizations. A commitment to change has been depicted as an adhesive tool that provides crucial bond between people and purpose of change itself (Baraldi et al., 2010). Most companies would like to reveal their employees' talents and enthusiasm through their commitment (Senge, 2014). Employee commitment seems to be crucial in decision making for any organizations to be able in business competition and to adapt with changes. The commitment among employees can be a crucial tool for improving their performance in organizations.

In the present study, focus was given to the role of internal communication (IC) as the individual variable that is purportedly able to explain its effect on employees' commitment to change. Many studies focused on vital role of internal communication in the change process (Walker et al., 2007) but there are still rare literatures that discussed its role in employees' commitment to change. A little evidence found on the relationship between internal communication and organizational commitment (Carrière \& Bourque, 2009). Previous studies found the positive relationship between communication and organizational commitment (Ng et al., 2006; Varona, 1996). Given the gaps in the theoretical understanding in this issue, this present study explored the effect of internal communication on employees' commitment to change. Communication is needed to raise awareness among employees on the need of change as well as creating the sense of urgency to the change whereby it leads to the commitment to change.

\section{Literature Review}

The discussions related internal communication have been more appealed in the beginning of twentieth century. Communication is another dimension that related to the successful organizational change. Communication is required to adapt with the change processes by those that are affected (Bull \& Brown, 2012). Without the effective employee communication, change is barely possible whereby it was ignored by most of companies. Communication is well known to establish change readiness, to decrease uncertainty and apparently as a crucial factor in obtaining commitment (Armenakis et al., 1993; Klein, 1994). According to Simoes and Esposito (2014), communication that aligns with the change gains commitment among employees by decreasing their tendency to resist the change. The relationship between communication and organizational change have been attracted the attention of previous researchers on the last decades (Johansson \&Heide, 2008). In raising awareness among employees on the necessity of change and creating a sense of belonging for sustainable and cohesive attempts to change are the importance of communication itself (Sundstro \& Annika, 2009). Jalil (2011) studied that internal communication hypothesizes the direct relationship 
with commitment to change among employees in strengthen their sense effectively. Likewise, several previous studies have stressed on the importance of communication role in change processes (Ford \& Ford, 1995; Kotter, 1996; Lewis \& Seibold, 1996; van Vuuren \& Elving, 2008). Even Lewis (1999) boldly stated that there is inseparably linked processes between communications and organizational change. The strong interest regarding internal communication due to the enhancement of a complex and modern organizations and the information technology used by companies to communicate and to interact with their subordinates (Bélanger \& Watson-Manheim, 2006; Byrne \& LeMay, 2006; Turner et al., 2006). The sense of disequilibrium with the current status quo will be increased with an effective internal communication (Raineri, 2011). The instability of current performance mandates change is need to be communicated timely and transparently to stakeholders; particularly the employees. Without a proper and adequate communication, it might make harder or irresponsible to execute the change plan, such as through the policy plan (Lai \& Ong, 2010).

Lai and Ong (2010) further stated that to increase employee consciousness, the organization should help the employees to understand that the status quo is undesirable. This can be done in formal or informal communication within departments or organizations (Raineri, 2011). Previous studies showed a good communication reduce employee's feelings of inertia, and provide them with the considerate that the change is imperative. Furthermore, it helps employees change their conceptual as well as the emotional viewpoints on their current status quo (Buchanan et al., 2005; Lai \& Ong, 2010). In support of this, Holt et al. (2007) suggested a more comprehensive approach including structured communication process to staff on compelling reasons for the intended change, the enablers and intended outcome. When adequate communication is deployed to employees, they will be more likely to understand and will resonate the idea of the insecurity of the current status and further open their mind. Communication is necessary to provide salient information and to insist the employees on doing something better. Communication will also promote sense of belonging among employees which is crucial to foster commitment and cohesiveness among employees (Raineri, 2011). Several authors argued that facilitating communication during the change process, allows employees to understand what, when and why the organization should adapt to the new circumstances (Dutton et al., 2001; Lewis et al., 2006). Employees should not only demonstrate the behaviors of the need to change, but also comprehend the reasons why the need of change is important in the current situation. Internalizing the reason for change would lead to a sustainable sense of urgency by employees as it appeals directly to the 'emotional buy-in' instead of only 'intellectual-buy-in'; a concept highlighted by Sparrow and Cooper (2003) while analyzing the struggle of Sony in embarking a major structural change in 2004. Employees tend to respond to the urgency of change when they can relate their own involvement individually in determining the future of the organization, hence, a strong sense of belonging and commitment. Therefore, it is believed that the communication will intensify employee awareness to embrace change. Johnson (2009) offered scenarios where communicating urgency and commitment in support of new way of doing things are crucial. 
Communication should match the urgency and commitment they express earlier, of an individual's perceived urgency level to support change.

Furthermore, Sundstro and Annika (2009) highlighted interaction within organization provided coordination and discussion on demand to change. It is suggested that the communication supported the need for change in organization provide opportunities for issues to be viewed from several perspectives, thus to be more open-minded. Intense communication has been shown to enhance the urge for betterment. They further suggested the communication on the objectives of changes in is vital in the sense of urgency. Communication is suggested to be crucial for the sense of urgency to move from the current state to the future state (Bordia et al., 2006; Kotter, 1996a; Martin et al., 2006; Meyer et al., 2006). Internal communication, such as open dialogue is to trigger awareness of the sudden need to change, as the way management promotes the change processes to the organization. Nevertheless, in communication a change of directions, clarity and transparency are most critical as cited by most studies. Clarity is imperative on making employees understand on why the company had to change, what was going to change, when and how change would be realized, and with the involvement of whom. The transparency of the communication gain trust that would enable commitment to change among employees. Some stressed that communication has to be a continuous process to enable total employees buy-in to the intended change (Blanchard \& Stoner, 2004).

Company which made frequent and solid communication efforts to ensure understanding and support of the change program will likely see the sense of urgency for change among employees rise (Hertog et al., 2010). The management should exemplify the needed changes in the company by playing a key role in the circulation of information of the change process. Based on the findings by Hertog et al. (2010), the majority of the firms considered communication as an effective tool to stimulate a sense of urgency. In most cases, communication serves as painful facts similar to shock therapy. Most of the firms began their change programs with one-way communication (broadcasting) to express the situations urgency and to justify far-reaching changes. Especially among the early adopters, participants explained that this was only the beginning of a communication process. The one-way communication had to be converted into a two-way system, both at the level of management-worker representatives and at the lower level of employees.

Communication is believed as a crucial tool in the successful change implementation due to it used as transmitter to announce, to explain, to inform and to prepare people for change for the positive and negative impacts of implementing the change itself. It enhances the understanding of commitment to change in order to prevent confusion and resistance to change (Kitchen \& Daly, 2002; Spike \& Lesser, 1995). Internal communication theory linked employees to their organization as it extends its scope to include linkages between internal communication and organizational commitment (Ruck \& Welch, 2012). A case study of 32 senior HR managers through in-depth interviews expected that managers to be more effective in interpersonal communication that focus mainly on the clarity and frequency of the 
messages, their ability to actively listen and the ability to lead in collaborative way. The way of messages was sent and a leadership style that engendered trust was the most important when HR managers wanted to enhance employee commitment to the organization (Bambacas \& Patrickson, 2008). It highlights that the interpersonal communication skills that enhance organizational commitment and are most valued by organizations are those that are most lacking in managers. Generally, literature that has considered communication that linked to commitment has focused on two areas. First, the focus has been on general aspects of communication such as communication satisfaction (Varona, 1996), communication climate (Guzley, 1992; Van den Hooff \& de Ridder, 2004), quality of communication (Thornill et al., 1996), communication systems (Jacobs, 2006) and their links to affective commitment. Second, specific facets of communication such as organizational information provision $(\mathrm{Ng}$ et al., 2006), relationship with upper level management (Putti et al., 1990) and their link to affective commitment has been considered.

In addition, a survey of 104 full-time employees by Awad and Alhashemi (2012) investigated the employees' motives for communicating with their superiors and co-workers, their satisfaction and commitment towards their organization. The importance of their study is to depict how employees' purposes for communication relate to satisfaction and commitment with their leaders, jobs and the company at which they work. It focused on job satisfaction, commitment, relationships at work and ways of building up such relationship with superiors, co-workers and with organization at large. The research also covers other related topics including barriers to organizational and interpersonal communication. The main purpose is to establish a link between relationships at work, job satisfaction and commitment in organizations. Hence the following research hypotheses are offered:

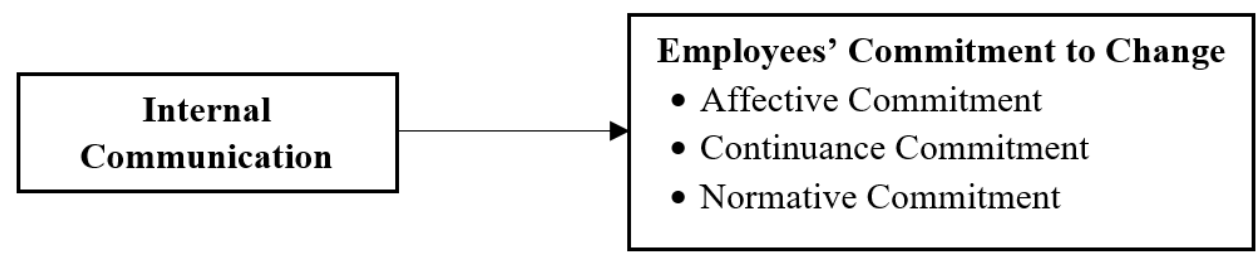

H1: There is a significant relationship between internal communication and affective commitment to change

H2: There is a significant relationship between internal communication and continuance commitment to change

H3: There is a significant relationship between internal communication and normative commitment to change

\section{Method}




\subsection{Sampling}

Data were collected from 311 employees in Malaysian large companies. According to Bursa Malaysia (2015), there are 812 listed companies whereby all of them are the large companies that surpassed the requirements as reputable companies in Malaysia. This research will stratify its sample into 30 largest companies that listed in FTSE Bursa Malaysia Kuala Lumpur Composite Index (FBM KLCI) Malaysia. This study applied a cluster sampling by identifying the number of large companies as well as the participants that required to be involved in the sample. The data only succeeded to collect the valid 311 questionnaires from 550 questionnaires that have been sent directly to the employees from different large companies in Malaysia that based generally in Kuala Lumpur and surroundings. All of participants were informed well about the purpose of this study in the questionnaires as well as boldly brief them about the confidentiality of their information in this survey. This survey took 15-20 minutes approximately in completing filled the questionnaires that were distributed on-site to the respondents directly.

The 311 participants (160 males and 151 females) had a ranged age of (32.7\%) 25-30 years, and on average had worked with their current company close to 5 years. The majority of the participants were Malay (84.3\%) as expected. Very few of them were of non-Malay race, possibly are Chinese and Indian descents but they are local people mostly. The participants were having 5-10 years (33\%) working experience and 1-5 years $(32.1 \%)$ working experience. The participants had achieved on average undergraduate level mostly at 67.6\% (hold bachelor degree) of education. They mostly worked in sales and marketing department (16\%) and administration department $(13.8 \%)$. They were also in entry level employees $(24 \%)$ and supervisors $(23.1 \%)$.

\subsection{Measures}

Employees' commitment to change. The measurement of employee commitment to change is based on the model of commitment to an organizational change of Herscovitch and Meyer (2001) in general theory of workplace commitment. Meyer and Allen (1997) stressed commitment as one of the most crucial factors that involved employees to support the change initiatives phenomenally. The instrument was adapted from Herscovitch and Meyer (2002). There are there dimensions under commitment: affective commitment, continuance commitment and normative commitment to change. Respondents were asked about their level of commitment in their companies, how strong their commitment towards it. They reported the scale of internal consistency of affective commitment at .92 , continuance commitment at .71 and normative commitment at .78 .

Internal communication. In order to adapt to the new circumstances, employees should facilitate the communication during the change processes (Dutton et al., 2001; Lewis, 2006). Communication is vital to create and maintain the relationship in order to create bonding among employees in organization that can engage them into commitment to their organizations (Awad \& Alhashemi, 2012). Hence, this variable consists of nine (9) items that 
was adapted from Hoyle (2010), Herold et al. (2008) and Paton et al. (2008). Reliability test is assessed to indicate that the items have the acceptable internal consistency. Commonly, the reliability for all items were acceptable in the minimum 0.60 (Bagozzi \& Yi, 1988); whereby the internal consistency for variable internal communication was 0.683. Each item was assessed by a five-point of Likert scale that raging from '1' "Strongly Disagree" to '5' "Strongly Agree" whereby all of items represented internal communication.

\section{Results}

Data were first checked for descriptive statistics such as frequency analysis to detect missing values and outliers before they were subject to further tests by using SPSS Version 22 software. Factor analysis was run on the main constructs: employees' commitment to change (affective, continuance and normative commitment) and internal communication. Based on factor analysis, the employees' commitment to change was found to be unidimensional, contrary to the original theoretical exposition. Next, reliability, correlation, and multiple regression analyses were run.

Table 1. Mean, Intercorrelations and Reliability Coefficients of Main Variables

\begin{tabular}{|c|c|c|c|c|c|c|c|}
\hline & Mean & S.D & $\boldsymbol{\alpha}$ & IC & AC & CC & NC \\
\hline Internal Communication & 3.53 & .94 & .86 & 1 & & & \\
\hline Affective Commitment to Change & 3.34 & .99 & .89 & $.545^{* *}$ & 1 & & \\
\hline Continuance Commitment to Change & 3.48 & 1.14 & .91 & $.562^{* *}$ & $.423^{* *}$ & 1 & \\
\hline Normative Commitment to Change & 3.47 & 1.17 & .92 & $.540^{* *}$ & $.422^{* *}$ & $.331^{* *}$ & 1 \\
\hline
\end{tabular}

** Correlation is significant at the 0.01 level (2-tailed).

$\mathrm{IC}=$ Internal communication; $\mathrm{AC}=$ Affective commitment $\mathrm{CC}=$ Continuance commitment; $\mathrm{NC}=$ Normative commitment

Table 1 shows the descriptive, correlations and reliability coefficients of the main variables. As indicated, the instruments that measured the main variables were deemed to be reliable, as the alpha coefficients were all beyond the acceptable level of .70 (Nunnally, 1978). Findings elaborate that all under study variables are significantly and positively correlated with each other.

Table 2. Multivariate Regression Analysis 


\begin{tabular}{|l|l|l|l|l|l|}
\hline Dependent Variable & Parameter & $\boldsymbol{\beta}$ & $\begin{array}{l}\text { Std. } \\
\text { Error }\end{array}$ & $\mathbf{t}$ & Sig. \\
& & & & & \\
\hline \multirow{2}{*}{$\begin{array}{l}\text { Affective commitment to Change } \\
\text { Continuance Commitment } \\
\text { Change }\end{array}$} & Intercept & 1.327 & .183 & 7.237 & .000 \\
\cline { 2 - 6 } & IC & .571 & .050 & 11.414 & .000 \\
\hline \multirow{2}{*}{\begin{tabular}{l} 
Normative Commitment to Change \\
\cline { 2 - 6 }
\end{tabular}} & Intercept & 1.084 & .208 & 5.208 & .000 \\
\cline { 2 - 6 } & IC & .678 & .057 & 11.933 & .000 \\
\cline { 2 - 6 } & Intercept & 1.117 & .217 & 5.150 & .000 \\
\hline
\end{tabular}

Independent Variable: Internal Communication

Table 2 shows the findings of multivariate regression analysis. Results proved that internal communication has significant and positive association with affective commitment ( $\beta=.571$, $\mathrm{p}<0.05, \mathrm{t}=11.41$ ) and supported to $\mathrm{H} 1$. Similarly results also divulged that that the significant and positive relationship between internal communication and continuance commitment $(\beta=.678, \mathrm{p}<0.05, \mathrm{t}=11.93)$ and supported to $\mathrm{H} 2$. Moreover, results also highlights that internal communication has significant and positive association with normative commitment $(\beta=.668, \mathrm{p}<0.05, \mathrm{t}=11.27)$ and supported to H3.

\section{Discussion}

This present study undertook to prove the research objective: To examine the influence of internal communication on employee commitment to change. It was revealed that internal communication is able to affect the collective employees' commitment to change of affective, continuance and normative commitment strongly in a company based on the empirical analysis that being observed. Internal communication allows the employees to gain trust from their companies through the effective internal communication, so that they will commit to their company to change. Generally speaking, the empirical observation lend support to existing literatures on the positive contribution of internal communication in organizational change (e.g. Bordia et al., 2006; Crestani, 2016; Jalil, 2011; Johansson \&Heide, 2008; Kotter, 1996a; Lewis, 1999; Martin et al., 2006; Meyer et al., 2006; Raineri, 2011; Simoes \& Esposito, 2014), suggesting that internal communication significantly affect the employees' commitment to change from all aspects (Awad \& Alhashemi, 2012; Bambacas \& Patrickson, 2008; Ruck \& Welch, 2012). However, the evidence somehow indicates that internal communication has different impact on different commitment. Yet, the impact for three aspects of commitment (affective, continuance and normative commitment) remains strong.

According to McKay et al. (2013), affective commitment is one of the aspects that is being affected by internal communication. Affective commitment refers to emotional attachment among employees to commit in a company (Khan et al., 2010). Internal communication strengthen the employees' trust through the enhancement feelings of the messages given from the organization towards employee levels of affective commitment (Meyer \& Smith, 2001). Researchers have generally found that the method of message is decoded is rely on how perceived and concluded (McShane \& Travaglione, 2003) whereby those quality of the 
feedbacks employees received that positively connect to their level of commitment (Beck \& Wilson, 1997; Francis-Smythe \& Smith, 1997) such as affective commitment (Bambacas \& Patrickson, 2008; Carrière \& Bourque, 2009). This also could explain the positive relationship found between internal communication and employees' affective commitment to change.

Continuance commitment refers to the consequences the employees perceived are connected to leave the companies (Khan et al, 2010). Whilst to date not many studies have looked into the effect of internal communication towards the employees' continuance commitment to change, yet this study has been supported by previous studies at which it found that internal communication worked as a lift to generate trust among employees' relationships (e.g., Meyer \& Smith, 2001; Togna, 2014). Rousseau (2004) stated that one of company's obligations towards their employees is offering them the opportunities for their career development as a psychological contract. Companies are required to provide the intense and frequent internal communication that beneficial for their career growth. The continuance commitment among employees might increase by giving them these attention and recognition (Suliman \& Iles, 2000). Normative commitment refers to the pressures among employees to stay in their company as resulted from the company's obligations. Some of important implications on practical contribution have been found in this study. Internal communication strengthen the employees' trust through the enhancement feelings through the messages given from the organization towards employee levels of normative commitment (Meyer \& Smith, 2001). According to Brown et al. (1995), normative commitment occurred among channel members whereby it increased coordination within channel as well as increased the experience for closer integration through communication (Wu et al., 2004). This present study suggested that the leaders and their subordinates to explore more about their current practices in handling the effective internal communication that based on the findings. Special attention ought to be provided in the implementation of effective internal communication particularly as this practice are likely to strengthen the occurrence of employees' commitment to change. In particular, the leaders need to understand that the thoughtful and meaningful words they communicated with employees gave the sense of values among employees. The values they experienced create their moral obligation to commit in their organization (Islam et al., 2014).

A prudent consideration ought to be taken on the findings regarding the importance of internal communication in affecting employees' commitment to change despite of its significant results. Regardless the singular limitation of variable internal communication, the adversities occurred on the attempting to involve all participants from large companies, yet, the HR department policy seemed complicate the data collection procedures. Consequently, the data collected not entirely represent all departments in large companies and even some of large companies rejected the attempt of data collection process of this study.

\section{Conclusion}


This present study undertook to investigate the importance of internal communication in affecting the employees' commitment to change. There is significant relationship between internal communication and employees' commitment to change on affective commitment, continuance commitment and normative commitment based on the empirical results that were found, whereby it suggested that internal communication affect the employees' attitude to engage and commit to change in their company. From the practical perspective, this present study encourages the company to explore more their internal communication practices effectively so that it can be useful for their organizational change.

In a nutshell, the commitment to change undoubtedly poses an interesting phenomenon in the development of business globally as a reaction to change. In fact, this issue can be seen as interesting opportunities and benefits among companies in order to develop their business despite of its challenges that affect the world of business industry. The respond of how organizations can communicate the change effectively to their subordinates and affect their attitudes to commit to the change itself seemed to be the most challenging issue. Studies on organizational change will attract many scholars in initiating the academic activities toward improving a better understanding about the importance of employees' commitment to change in terms of theoretical perspective.

\section{References}

Abrell-Vogel, C., \& Rowold, J. (2014). Leaders' commitment to change and their effectiveness in change - A multilevel investigation. Journal of Organizational Change Management, 27(6), 900-921. http://dx.doi.org/10.1108/JOCM-07-2012-0111

Ahmad, H., \& Gelaidan, H. (2011). Organizational culture, leadership styles and employee's commitment to change: A case of Yemen public sector. The Journal of Organizational Management Studies, 2011, 1-10. http://dx.doi.org/10.5171/2011.722551

Ahmad, N., \& Seet, P. (2009). Dissecting behaviors associated with business failure: A qualitative study of SME owners in Malaysia and Australia. Asian Social Science, 5(9), 98. http://dx.doi.org/10.5539/ass.v5n9p98

Awad, T., \& Alhashemi, S. (2012). Assessing the effect of interpersonal communications on employees' commitment and satisfaction. International Journal of Islamic and Middle Eastern Finance and Management, 5(2), 134-156. http://dx.doi.org/10.1108/17538391211233425

Bagozzi, R., \& Yi, Y. (1988). On the evaluation of structural equation models. Journal of The Academy of Marketing Science, 16(1), 74-94. http://dx.doi.org/10.1007/BF02723327

Bambacas, M., \& Patrickson, M. (2008). Interpersonal communication skills that enhance organizational commitment. Journal of Communication Management, 12(1), 51-72. http://dx.doi.org/10.1108/13632540810854235

Baraldi, S., Kalyal, H., Berntson, E., Näswall, K., \& Sverke, M. (2010). The importance of 
commitment to change in public reform: An example from Pakistan. Journal of Change Management, 10(4), 347-368. https://doi.org/10.1080/14697017.2010.516482

Bélanger, F., Watson-Manheim, M. (2006). Virtual teams and multiple media: Structuring use to attain strategic goals. Group Decision and Negotiation, 15(4), 299-321. http://x.doi.org/10.1007/s10726-006-9044-8

Bellou, V., \& Chatzinikou, I. (2015). Preventing employee burnout during episodic organizational changes. Journal of Organizational Change Management, 28(5), 673-688. http://dx.doi.org/10.1108/JOCM-11-2014-0197

Blanchard, K., \& Stoner, J. (2004). The vision thing: Without it you will never be a world-class organization. Leader to Leader, 2004(31), 21-28.

Bricongne, J., Fontagné, L., Gaulier, G., Taglioni, D., \& Vicard, V. (2012). Firms and the global crisis. French exports in the turmoil. Journal of International Economics, 87(1), 134-146. http://dx.doi.org/10.1016/j.jinteco.2011.07.002

Brown, J., Lusch, R., \& Nicholson, C. (1995). Power and relationship commitment: Their impact on marketing channel member performance. Journal of Retailing, 71(4), 363-392. http://dx.doi.org/10.1016/0022-4359(95)90019-5

Buchanan, D., Fitzgerald, L., Ketley, D., Gollop, R., Jones, J., Lamont, S., Neath, A., Whitby, E. (2005). No going back: A review of the literature on sustaining organizational change. International Journal of Management Reviews, 7(3), 189-205. http://dx.doi.org/10.1111/j.1468-2370.2005.00111.x

Bull, M., \& Brown, T. (2012). Change communication: The impact on satisfaction with $\begin{array}{llll}\text { alternative } \quad \text { workplace } \quad \text { strategies. } & \text { Facilities, } & 30(3 / 4), & \text { 135-151. }\end{array}$ http://dx.doi.org/10.1108/02632771211202842

Burke, W. (2002). Organization change: Theory and practice. CA: Jossey-Bass Thousand Oaks.

Burke, W. (2013). Organization change: Theory and practice. Dias Technology Review, 7(2), 72-82. UK: Sage Publications.

Bursa Malaysia (2015). Sustainability reporting guide.

Byrne, Z., LeMay, E. (2006). Different media for organizational communication: Perceptions of quality and satisfaction. Journal of Business and Psychology, 21(2), 149-173. http://dx.doi.org/10.1007/s10869-006-9023-8

Carrière, J., \& Bourque, C. (2009). The effects of organizational communication on job satisfaction and organizational commitment in a land ambulance service and the mediating role of communication satisfaction. Career Development International, 14(1), 29-49. http://dx.doi.org/10.1108/13620430910933565 
Chen, J., Wang, L., Huang, M., \& Spencer-Rodgers, J. (2012). Naive dialecticism and Chinese employees' commitment to change. Journal of Managerial Psychology, 27(1), 48-70. http://dx.doi.org/10.1108/02683941211193857

Child, J. (2015). Organization: Contemporary principles and practice. John Wiley and Sons.

Crestani, I. (2016). Change communication: Emerging perspectives for organizations and practitioners. Advances in Public Relations and Communication Management, 1, 225-244. http://dx.doi.org/10.1108/S2398-391420160000001012

Cummings, T., \& Worley, C. (2014). Organizational development and change ( $9^{\text {th }}$ ed.). US: South-Western Cengage Learning.

Dutton, J., Ashford, S., O’Neill, R., \& Lawrence, K. (2001). Moves that matter: Issue selling and organizational change. Academy of Management Journal, 44(4), 716-736. http://dx.doi.org/10.2307/3069412

Erkutlu, H., \& Chafra, J. (2016). Value congruence and commitment to change in healthcare organizations. Journal of Advances in Management Research, 13(3), 316-333. http://dx.doi.org/10.1108/JAMR-11-2015-0078

Ford, J., \& Ford, L. (1995). The role of conversations in producing intentional change in organizations. Academy of Management Review, 20(3), 541-570. http://dx.xoi.org/10.5465/AMR.1995.9508080

Fortune (2015). Big tech firms, food companies commit to White House climate change pledge. $\quad$ Retrieved $\quad$ on $16 \quad$ May 2016 at http://fortune.com/2015/10/19/white-house-climate-pledge/

Gelaidan, H., \& Ahmad, H. (2010). The effect of leadership style on affective commitment to change and moderating of organizational culture in Yemen public sector: Development of a conceptual model, 2010, 13-24.

Guzley, R. (1992). Organizational climate and communication climate: Predictors of commitment to the organization. Management Communication Quarterly, 5(4), 379-402. https://doi.org/10.1177/0893318992005004001

Herold, D., Fedor, D., Caldwell, S., \& Liu, Y. (2008). The effects of transformational and change leadership on employees' commitment to a change: A multilevel study. Journal of Applied Psychology, 93(2), 346. http://psycnet.apa.org/doi/10.1037/0021-9010.93.2.346

Herscovitch, L., \& Meyer, J. (2002). Commitment to organizational change: Extension of a three-component model. Journal of Applied Psychology, 87(3), 474. http://psycnet.apa.org/doi/10.1037/0021-9010.87.3.474

Hertog, F., Iterson, A., \& Mari, C. (2010). Does HRM really matter in bringing about strategic change? Comparative action research in ten European steel firms. European Management Journal, 28, 14-24. http://dx.doi.org/10.1016/j.emj.2008.11.002 
Holt, D., Armenakis, A., Field, H., \& Harris, S. (2007). Readiness for organizational change: The systematic development of a scale. Journal of Applied Behavioral Science, 43, 232-255. https://doi.org/10.1177/0021886306295295

Hoyle, D. (2010). Managing processes effectively (a new model for managing processes). Quality World, 36(3), 32-36.

Islam, T., Kassim, N., Ali, G., \& Sadiq, M. (2014). Organizational learning culture and customer satisfaction: The mediating role of normative commitment. The Learning Organization, 21(6), 392-404. http://dx.doi.org/10.1108/TLO-07-2014-0040

Jaafar, M., \& Abdul-Aziz, A. (2005). Resource-based view and critical success factors: A study on small and medium sized contracting enterprises (SMCEs) in Malaysia. International Journal of Construction Management, 5(2), 61-77.

Jacobs, G. (2006). Communication for commitment in remote technical workforces. Journal $\begin{array}{llll}\text { of communication } \quad \text { Management, } & \text { 10(4), }\end{array}$ http://dx.doi.org/10.1108/13632540610714809

Jalil, J. (2011). The relationship between personality traits, internal communication, transformational leadership and sense of urgency: A mixed method study of Repso Malaysia (Doctoral dissertation, Universiti Utara Malaysia).

Johansson, C., Heide, M. (2008). Speaking of change: Three communication approaches in studies of organizational change. Corporate Communication: An International Journal, 13(3), 288-305. http://dx.doi.org/10.1108/13563280810893661

Johnson, J. (2009). Assessing workers' true and perceived sense of urgency during strategic change: A descriptive and correlational examination. ProQuest.

Khan, M., Ziauddin, Jam, F., \& Ramay, M. (2010). The impacts of organizational commitment on employee job performance. European Journal of Social Sciences, 15(3), 292-298.

Kitchen, P., \& Daly, F. (2002). Internal communication during change management. Corporate communication: An International Journal, 7(1), 46-53. http://dx.doi.org/10.1108/13563280210416035

Kotter, J. (1996). Leading change. US: Harvard Business Press.

KPMG International (2008). A Rough Road: The effects of today's financial crisis on the global automotive industry, at http://www.kpmg.com/SiteCollectionDocuments/A_rough_road_financial_crisis.pdf.

Lai, J., \& Ong, C. (2010). Assessing and managing employees for embracing change: A multiple-item scale to measure employee readiness for e-business. Technovation, 30(1), 76-85. http://dx.doi.org/10.1016/j.technovation.2009.05.003 
Lewis, L. (2006). Employee perspectives on implementation communication as predictors of perceptions of success and resistance. Western Journal of Communication, 70(1), 23-46. http://dx.doi.org/10.1080/10570310500506631

Lewis, L., \& Seibold, D. (1996). Communication during intraorganizational innovation adoption: Predicting users' behavioral coping responses to innovations in organizations. 131-157. http://dx.doi.org/10.1080/03637759609376383

Luo, W., Song, L., Gebert, D., Zhang, K., \& Feng, Y. (2016). How does leader communication style promote employees' commitment at times of change? Journal of $\begin{array}{lll}\text { Organizational Change } \quad \text { Management, } & \text { 29(2), }\end{array}$ http://dx.doi.org/10.1108/JOCM-11-2014-0204

McKay, K., Kuntz, J., \& Naswall, K. (2013). The effect of affective commitment, communication and participation on resistance to change: The role of change readiness. New Zealand Journal of Psychology, 42(2), 29-40.

Meyer, J., \& Allen, N. (1997). Commitment in the workplace. London: Sage Publications.

Meyer, J., \& Herscovitch, L. (2001). Commitment in the workplace: Toward a general model. Human Resource Management Review, 11(3), 299-326. http://dx.doi.org/10.1016/S1053-4822(00)00053-X

Meyer, J., \& Smith, C. (2001). HRM practices and organizational commitment: Test of a medication model. Canadian Journal of Administrative Sciences, 14(4), 319-331.

Mousavi, M., Aziz, F., \& Ismail, N. (2011). Selection on appropriate departments for virtual reality implementation in Malaysian automotive manufacturing industry. International Conference on Sociality and Economics Development, 10.

Ng, T., Butts, M., Vandenberg, R., DeJoy, D., \& Wilson, M. (2006). Effects of management communication, opportunity for learning, and work schedule flexibility on organizational commitment. Journal of Vocational Behavior, 68(3), 474-489. http://dx.doi.org/10.1016/j.jvb.2005.10.004

Nunnally, J. (1978). Psychometric methods. NY: McGraw-Hill.

Ong, S., Yap, V., \& Khong, R. (2011). Corporate failure prediction: A study of public listed companies in Malaysia. Managerial Finance, 37(6), 553-564. http://dx.doi.org/10.1108/03074351111134745

Paton, B., Beranek, L., \& Smith, I. (2008). The transit lounge: A view of organizational change from a point in the journey. Australia Library Management, 29(1), 87-103. http://dx.doi.org/10.1108/01435120810844676

Paulet, E., Parnaudeau, M., \& Abdessemed, T. (2014). The SME struggle for financing: A clampdown in European banks post-crisis. Journal of Business Strategy, 35(2), 36-45. http://dx.doi.org/10.1108/JBS-09-2013-0089 
Probst, G., \& Raisch, S. (2005). Organizational crisis: The logic of failure. The Academy of Management Executive, 19(1), 90-105. http://dx.doi.org/10.5465/AME.2005.15841958

Putti, J., Aryee, S., \& Phua, J. (1990). Communication relationship satisfaction and organizational commitment. Group and Organization Management, 15(1), 44-52. https://doi.org/10.1177/105960119001500104

Raineri, A. (2011). Change management practices: impact on perceived change results. Journal of Business Research, 266-272. http://dx.doi.org/10.1016/j.jbusres.2009.11.011

Ruck, K., \& Welch, M. (2012). Valuing internal communication; management and employee $\begin{array}{llll}\text { perspectives. } \quad \text { Public } & \text { Relations } & \text { 294-302. }\end{array}$ http://dx.doi.org/10.1016/j.pubrev.2011.12.016

Senge, P. (2014). The dance of change: The challenges to sustaining momentum in a learning organization (eds.). NY: Doubleday.

Simoes, P., \& Esposito, M. (2014). Improving change management: How communication nature influences resistance to change. Journal of Management Development, 33(4), 324-341. http://dx.doi.org/10.1108/JMD-05-2012-0058

Sparrow, P., \& Cooper, C. (2003). The employment relationship: Key challenges for HR. London: Butterworth Heinemann.

Spike, B., \& Lesser. (1995). We have met the enemy. Journal of Business Strategy, 16(2), 17-23.

Suliman, A., \& Iles, P. (2000). Is continuance commitment beneficial to organizations? Commitment-performance relationship: A new look. Journal of Managerial Psychology, 15(5), 407-422. http://dx.doi.org/10.1108/02683940010337158

Sundstro, P., \& Annika, Z. (2009). Organizing for innovation in a product development project: Combining innovative and result oriented ways of working- a case study. International Journal of Project Management, 27, 745-753. http://dx.doi.org/10.1016/j.ijproman.2009.02.007

Thornhill, A., Lewis, P., Saunders, M. (1996). The role of employee communication in achieving commitment and quality in higher education. Quality Assurance in Education, 4(1), 12-20. http://dx.doi.org/10.1108/09684889610107995

Togna, G. (2014). Does internal communication to generate trust always increase commitment? A study at Micron Technology. Corporate Communications: An International Journal, 19(1), 64-81. http://dx.doi.org/10.1108/CCIJ-07-2012-0046

Tuanmat, T., \& Smith, M. (2011). Changes in management accounting practices in Malaysia. Asian Review of Accounting, 19(3), 221-242. http://dx.doi.org/10.1108/13217341111185146 
Turner, J., Grube, J., Tinsley, C., Lee, C., \& O'Pell, C. (2006). Exploring the dominant media. Journal of Business Communication, 43(3), 220-250. https://doi.org/10.1177/0021943606288772

Van de Hooff, B., \& de Ridder, J. (2004). Knowledge sharing in context: The influence of organizational commitment, communication climate and CMC use on knowledge sharing. Journal of Knowledge Management, 8(6), 117-130. http://dx.doi.org/10.1108/13673270410567675

Van Vuuren, M., \& Elving, W. (2008). Communication, sensemaking and change as a chord of three strands: Practical implications and a research agenda for communicating organizational change. Corporate Communications: An International Journal, 13(3), 349-359. http://dx.doi.org/10.1108/13563280810893706

Varona, F. (1996). Relationship between communication satisfaction and organizational commitment in three Guatemalan organizations. Journal of Business Communication, 33(2), 111-140. http://dx.doi.org/10.1177/002194369603300203

Walker, J., Armenakis, A., \& Bernerth, J. (2007). Factors influencing organizational efforts: An integrative investigation of change content, context, process and individual differences. Journal of Organizational Change, 20(6), 761-773. http://dx.doi.org/10.1108/09534810710831000

Walmsley, D., \& Lewis, G. (2014). People and environment: Behavioral approaches in human geography. Routledge.

Wooten, M., \& Hoffman, A. (2016). Organizational field past, present and future. Ross School of Business Pater, 1311.

Wu, W., Chiag, C., Wu, Y., \& tu, H. (2004). The influencing factors of commitment and business integration on supply chain management. Industrial Management and Data Systems, 104(4), 322-333. http://dx.doi.org/10.1108/02635570410530739

Yap, B., Munuswamy, S., \& Mohamed, Z. (2012). Evaluating company failure in Malaysia using financial ratios and logistics regression. Asian Journal of Finance and Accounting, 4(1), 330-344. http://dx.doi.org/10.5296/ajfa.v4i1.1752

\section{Copyright Disclaimer}

Copyright for this article is retained by the author(s), with first publication rights granted to the journal.

This is an open-access article distributed under the terms and conditions of the Creative Commons Attribution license (http://creativecommons.org/licenses/by/3.0/). 